Наводяться результати досліджень використання шротів олійних культур y технологї борошняних кондитерських виробів, а саме пісочного тіста. Досліджено структурно-механічні характеристики пісочного тіста із додаванням иротів насіння кунжуту, горіху $і$ льону. Виявлено, що показники еластичності, пластичності $і$ розтяжності зменшуються у порівнянні із контрольним зразком від $4 \%$ до $40 \%$ при додаванні шротів кунжуту, горіху та льону з вмістом від $10 \%$ до 30 \%. Додавання шротів сприяє зменшенню кількості клейковини борошна, що є позитивним иинником для формування пісочного тіста. При додаванні композиції вказаних шротів у співвідношенні 1,5:2:1,5 у пісочне тісто збільшується вміст білка, клітковини, макро- та мікроелементів.

Проведено сенсорну оцінку якості пісочних тістових напівфабрикатів із шротами олійних культур. Розраховано розтяжність контрольного $і$ дослідних зразків тістових пісочних напівфабрикатів із заміною $10 \%, 20 \%$ i $30 \%$ композииії замість борошна. Розраховано структурно-механічні характеристики пісочного тіста - деформащію, відносну пластичність, еластичність, пружність. Побудовано графік динаміки деформації пісочного тіста з використанням модельних композицій шротів кунжуту, горіху та льону. У розроблених тістових напівфабрикатах зменшуються показники пластичності, еластичності, пружності та деформачії. Визначено, що кількість клейковини у пісочному тісті зменшується $i$ розроблені вироби мають більшу крихкість. Визначено, що найкращі сенсорні показники має зразок із 20 \% вмістом шротів у борошні.

Експериментально підтверджено доцільність використання шротів олійних культур, а також розроблено технологію борошняних кондитерсъких виробів із пісочного тіста. В нъому збільшився вміст білка в 2,4 рази, Селену в 41,2 рази, клітковини - в 4,7 рази, Кальцію - в 18,4 рази, Магнію - в 8,5 рази, вітаміну $E$ - в 9,1 рази. Встановлено, що розроблені функціональні вироби мають покращену харчову $i$ біологічну цінність та крихкість

Ключові слова: пісочне тісто, шроти, олійні культури, структурно-механічні характеристики, деформація тіста

\section{RESEARCH INTO THE STRUCTURAL-MECHANICAL PROPERTIES OF SHORTBREAD DOUGH WITH OILSEED MEALS}

\author{
M. Kravche n ko \\ Doctor of Technical Sciences, Professor* \\ V. Mihailik \\ Engineer, Postgraduate student* \\ D. Y a k y m c h u k \\ $\mathrm{PhD}$, Associate Professor $* * *$ \\ E-mail: starcon84@gmail.com
}

O. D z y u n d z y a

$\mathrm{PhD}$, Associate Professor***

V. B u r a k

$\mathrm{PhD}$, Associate Professor

Department of Food Engineering

Kherson State Agrarian University

Stritenska str., 23, Kherson, Ukraine, 73006

O. Rom a n e n ko

$\mathrm{PhD}$, Associate Professor

Department Commodity Science, Safety and Quality Management**

M. Valko

Doctor of Technical Sciences, Professor $* \star \star *$

E. Korolenko

$\mathrm{PhD}$, Associate Professor $\star * \star *$

I. O s y pe n k ov a

$\mathrm{PhD}$, Associate Professor $* \star \star \star *$

Z. B o ndarch u k

$\mathrm{PhD}$, Associate Professor $* * * * *$

*Department of Technology and

Restaurant Establishment Organization**

**Kyiv National University of Trade and Economics

Kyoto str., 19, Kyiv, Ukraine, 02156

$\star * *$ Department of Hotel-Restaurant and Tourism Business

Kherson State University

40 rokiv Zhovtnya str., 27, Kherson, Ukraine, 73000 $\star * * *$ Department of Food Technologies Kherson National Technical University

Beryslavske highway, 24, Kherson, Ukraine, 73008 $* * * * *$ Department of Food Technologies Cherkasy State Technological University Shevchenka blvd., 460, Cherkasy, Ukraine, 18006

\section{Introduction}

Though the flour-based confectionary products do not belong to social food, they belong to the category of products that are regularly consumed and are always in demand. From the point of view of healthy nutrition, they are characterized by a high content of carbohydrates, fats, as well as the unbalanced chemical composition [1]. Such specificity of people's 
nutrition is ineffective and causes a deterioration in health. Inadequate diet is the cause of many physical disorders, worsening the overall well-being of population. In addition, this is contributed to by many factors, which include: the culture of eating, low purchasing power, ignorance in matters of healthy and valuable food [2].

In view of the above, the measures are required that would protect people from the effect of food shortages, which would emphasize the balanced diet by adjusting a chemical composition. Therefore, of particular importance is the development and industrial implementation of products for preventive and special purposes, which contain vitally important micro-elements that are able to compensate for the effect of aggressive environmental factors.

Given this, it is a relevant task to optimize the chemical composition and biological value of flour-based confectionery products through the use of natural raw materials, which has high nutritional and biological value, rich in vitamins and micro-and macro-elements - potassium, calcium, iodine, selenium [3].

A promising direction when developing pastry products of high nutritional value is to use flour-based composite mixtures of oil-seed meals. The mixtures are composed of various components, whose amount and ratio depend on their purpose, making it possible to form new kinds of products on the basis of the mutual enrichment of their constituents.

Changing the components of mixtures, as well as their different ratio, affect the rheological properties of dough and makes it possible to use the composite mixtures when making shortbread confectionary. The use of oilseed meals improves the products' protein quality in terms of amino acid composition, improves fat-acid composition and increases the content of micronutrients. The meals enhance the functional capabilities of human body and prevent the exposure to harmful factors that impact humans [4].

Improving the quality of finished products while simultaneously ensuring high organoleptic indicators is an important task for both the enterprises in the hotel and restaurant industry and the food industry in general [5].

Modern trends in the development of food technologies are characterized by wide use of natural additives [6]. This applies to both Ukraine and most countries of the world. This trend ensures the extension of range of products, which are characterized by improved characteristics in comparison with conventional ones. Especially intensive development has been demonstrated by plant-derived supplements as additional ingredients to food products, including flour-based ones.

Therefore, it is a relevant task to explore the structural-mechanical properties of flour products with the addition of biologically active substances based on plant supplements.

\section{Literature review and problem statement}

To improve the structure of people nutrition, it is required to introduce modern technologies, formulations, to use new additives with a wide application of biologically active substances, such as vitamins, proteins, and amino acids. One of the sources of biologically active substances are plant supplements. They contain natural complexes of macroand micro-elements in the most accessible and digestible form [4]. One of such mineral supplements is meal. It is a byproduct of processing the seeds of flax, sesame, walnut kernels, received after subtracting oils from them. A charac- teristic feature of such a supplement is the powder-like structure and the enhanced content of fiber, protein, vitamins of group B, minerals. Among the available body of research into the application of meal as a biological supplement, worth noting is a series of major studies, which have the greatest impact on the results of further research.

It is known from [7] that the meal made from the leaves of walnut was used as a biologically active additive. The authors identified the chemical and fractional composition of such a powder. They established the higher content of selenium in a easily-digestible form, as well as proved the manifestation of anticancerogenic effect. It was determined that the walnut meal, when compared with wheat flour, contains significant amount of fiber, proteins with enhanced amino acid composition. In addition, it contains minerals (iron, potassium, manganese, copper, zinc) and some phenolic compounds, tannins, and flavonoids [7]. However, the use of nut kernel was not examined.

Paper [8] defined the rational dosage of flax seeds in shortbread biscuits. It was established that flax meal boosts the immune system, has a soothing effect, contributes to improving the processes of the gastrointestinal tract. A study reported in [8] has made it possible to establish that the presence of mineral substances in shortbread biscuits (magnesium, potassium, dietary fiber, vitamins A, B, E, amino acids, fatty acids $\omega^{-3}$ and $\omega^{-6}$ ) ensures an improvement in the organoleptic and functional characteristics. Adding the flax seed meal instead of flour in the amount of $2.5 \%$ to $7.5 \%$ increases the content of fiber, calcium, magnesium, selenium. However, in this case, flour products demonstrate the worsened structural-mechanical properties of dough.

It has been investigated that the oil-seed meals possess improved functional and technological properties, especially pronounced are the sorption, antioxidant, detoxic and complex-forming properties [9]. This improves the quality of finished products and the efficiency of application.

There is a known technology for using meal as a gluten-free additive when making bread [10]. It was established that adding such a supplement in the amount of $7-2 \%$ to the formulation composition of flour products increases the concentration of macro- and micronutrients. It has a positive effect on the nutritional value of products, especially for specific groups of people who are not advised to consume flourbased products. However, the study applies only to one of the products and does not give an idea of applying the specified meals when making other products.

Article [11] examined the influence of sugar substitutes on quality of confectionery. The authors defined a comprehensive indicator for quality of sugar and sugar substitutes, and established their impact on the manufacture of flour products. They specified the benefits of sugar substitutes in comparison with conventional sugar when adding them to products made of dough. It is worth noting that sugar substitutes make up a small percentage of the total quantity of raw materials in the manufacture of pastry products, so they produce little effect on the finished product. The specified article reports analysis of the influence of sugar substitutes on flour products as the elements that improve the properties of dough-based products. In addition to meals, other elements are used, which also should be mentioned.

There are studies reported by scientists in [12] that are related to increasing the biological value of gingerbread by using natural supplements. It was theoretically substantiated and experimentally confirmed that it was appropriate to apply 
plant supplements in the manufacture of such products. The authors substantiated the influence of the content of plant supplements on shape stability of gingerbread. However, the studies are theoretical in nature and do not lead to practical application.

Paper [13] described a technology of flour confectionery products that uses kernel of sunflower seeds. The authors defined the organoleptic characteristics and examined their influence on product quality. The positive effect has been established from the use of kernel of sunflower seeds in the manufacture of pastry products. The research reported is comprehensive in character while limited to mostly a theoretical aspect.

A study in [14] used meals from grape seeds in the manufacture of flour [14]. The authors described the advantages of using such flour in the manufacture of flour products. The study reported was aimed at dietary aspects of application and cannot be widely used.

Article [15] describes the use of chokeberry powder in the sponge cake technology for functional purposes of the type «Red Velvet». The authors investigated the benefits of using such an additive, as well as the basic functional capabilities. They devised a technology and the formulation for manufacturing original food products. It is worth noting that their development applies only to the manufacture of sponge cakes and does not make it possible to understand how the specified powder would affect other flour products.

Thus, despite the growing number of scientific papers regarding various supplements and meals in the manufacture of flour products, the application of compositions of oilseed meals has not been studied sufficiently. This is especially true for the meals of flax, sesame and walnut kernels that could be used when making products from shortbread dough.

\section{The aim and objectives of the study}

The aim of this study is to scientific substantiate and experimentally confirm the expediency of using the seed meals of sesame, walnut, and flax in the technology for manufacturing products from shortbread dough.

To accomplish the aim, the following tasks have been set:

- to explore the structural and mechanical characteristics of shortbread dough when adding the seed meals of sesame, walnut, and flax;

- to calculate the chemical composition of shortbread biscuits and establish the expediency of application of the seed meals of sesame, walnut, and flax as a supplement to it;

- to conduct a sensory evaluation of the organoleptic indicators for finished products containing the composition of meals.

\section{Materials and methods to study shortbread dough with oil-seed meals}

In the experiments we used existing test research methods [16] and the rheological methods to study raw materials [17]. All raw materials and materials complied in terms of quality and safety to the requirements of Ukraine's acting standard DSTU 3781:2014 [18]. They were certified by manufacturers and their use is allowed by the Ministry of Health of Ukraine. In this work, we employed the methods for determining the mass share of moisture and solids according to DSTU 4910:2008 [19].
Elongation was determined at the elastoplastometer by Tolstoy (Ukraine) [17]. The elastoplastometer is composed of the following elements: a table atop which is a support for mounting a plate with a sample of dough; a microscope to study the shift of a needle; a unit that transmits a load to the upper plate using a suspended weight.

A measurement method is based on determining shear deformation with respect to the thickness of a sample. The typical measure of process is not deformation but pliability, that is the deformation with respect to the permanently applied stress. Pliability under conditions of linear behavior is constant and does not depend on stress. A first value for absolute deformation is obtained instantaneously from the microscope as soon as loading begins to act on the upper plate. Next, at intervals of 1 minutes, we acquire values for the absolute deformation over 10 minutes. Further observations can be carried out at intervals of 5 minutes. After removal of the load, the instantaneous deformation is registered; then we acquire readings from the device at the same frequency as it was during loading. The experiment is terminated if over 30 minutes it was not possible to register a change in absolute deformation.

The organoleptic indicators for shortbread dough were determined by tasting based on a ten-point scale according to DSTU 5024:2008 [20]. The examined material included the seed meal of sesame, walnut, and flax, which match TU 10.4-38667335-002:2014 [21].

The object of our study was the composition of seed meals from sesame, flax, walnut. The optimal ratio of the three kinds of meals in the composition was determined by the method of mathematical modeling. The optimal ratio of meals from sesame, walnut, flax was defined to be 1.5:2:1.5. The resulting composition of meals was used in the further research. It was introduced to shortbread dough in the amount of $10 \%, 20 \%$, and $30 \%$ by weight of flour according to the formulation (experiment 1, 2, and 3, respectively). To this end, we used 4 samples of shortbread dough using the highest-grade wheat flour and the seed meals from sesame, flax, walnut, which formed the following shortbread dough semi-finished products:

- sample 1 - control (shortbread dough);

- sample 2 - shortbread dough where flour was replaced with the composition of meals from flax, sesame, walnut in the amount of $10 \%$ (experiment No. 1);

- sample 3 - shortbread dough where flour was replaced with the composition of meal from sesame, walnut, flax in the amount of $20 \%$ (experiment No. 2);

- sample 4 - shortbread dough where flour was replaced with the composition of meal from sesame, walnut, flax in the amount of $30 \%$ (experiment No. 3).

Studying the chemical composition of shortbread biscuits employed generally accepted standard methods of research. The chemical composition was investigated in line with DSTU 4910:2008, DSTU 4230:2003, DSTU 4638:2006, DSTU ISO 771:2006, specifically;

- the mass fraction of water - by a method of drying at a temperature of $100-105^{\circ} \mathrm{C}$ (stated above according to DSTU 4910:2008);

- fat - by extraction-weight method in the in the Soxhlet apparatus;

- protein - by determining total nitrogen by the Kjeldahl method;

- ash - by a weight method after a batch of the product mineralized in a muffle furnace at a temperature of $500-600^{\circ} \mathrm{C}$.

Quantitative changes in macro and micro-elements were determined by a method of atomic absorption spectropho- 
tometry at the device C-115 PK («NPP Akadempribor», Ukraine), using an acetylene air mixture. The content of mineral elements was determined by a method of x-ray fluorescence analysis at the analyzer ElvaX-Med (Elvatech, Ukraine); the content of calcium and phosphorus - by a colorimetric method; the content of iodine - by inversion voltammetry at the device AVA (OOO «UkrAnalitika», Ukraine).

\section{Results of research into the influence of oilseed meals on the structural-mechanical properties of shortbread dough}

In the study of influence of oilseed meals on the shortbread dough quality, it is important to examine the structuralmechanical properties of a semi-finished product. According to studies [22, 23], it was found that the structural-mechanical or rheological properties of foods characterize their capability to resist the influence of external energy. This is due to the structure of the product, as well as the quality of food products, which is mandatorily taken into consideration when choosing the conditions for their production and storage.

These characteristics include: distensibility, elasticity, plasticity, as well as dough viscosity. The specified characteristics largely depend on the quantitative ratio of protein and starch, the type of fat, conditions, and bonds. Distensibility and elasticity are due to the amount and properties of gluten, and plasticity and viscosity - to the size, structure, and state of starch grains, the presence of mucoid and non-starch polysaccharides. When considering these structural-mechanical properties, there is a possibility to develop new formulations or to improve those already applied.

\section{1. Determining the structural-mechanical indicators} for a shortbread dough semi-finished product

One of the basic indicators for a shortbread dough semi-finished product is distensibility, which is the basis to calculate elasticity, plasticity, and viscosity. Thus, at the first stage we examined the distensibility of control and experimental samples. The research results are given in Table 1.

Our research has made it possible to establish that the distensibility of shortbread dough semi-finished products when stretching over $90 \mathrm{~min}$ increased in control sample and reached from $0.12 \mathrm{~mm}$ to $0.94 \mathrm{~mm}$. For the experimental samples containing meals the distensibility with an increase in time was: experiment 1 - from $0.04 \mathrm{~mm}$ to $0.28 \mathrm{~mm}$; experiment 2 from $0.04 \mathrm{~mm}$ to $0.38 \mathrm{~mm}$; experiment 3 - from $0.04 \mathrm{~mm}$ to $0.26 \mathrm{~mm}$. The research has found that the distensibility of experimental shortbread dough semi-finished products containing meals decreases during experiments No. 1-3 compared with control sample by $0.68 \mathrm{~mm}, 0.56 \mathrm{~mm}$, and $0.70 \mathrm{~mm}$, $0.66 \mathrm{~mm}, 0.56 \mathrm{~mm}$, and $0.68 \mathrm{~mm}$, respectively. The distensibility of control sample increased by the following magnitudes: experiment No. 1 - $70.21 \%$, experiment No. 2 $59.57 \%$, experiment No. $3-72.34 \%$. Thus, adding the seed meal from sesame, walnut, flax to dough semi-finished products improves their consumer characteristics.

Based on data for distensibility, we have defined the structural-mechanical properties of shortbread dough. Calculation results are given in Table 2.

Table 1

Indicators of distensibility for shortbread dough semi-finished products

\begin{tabular}{|c|c|c|c|c|c|}
\hline \multirow{3}{*}{$\begin{array}{l}\text { No. of } \\
\text { entry }\end{array}$} & \multirow{3}{*}{$\begin{array}{l}\text { Time, } \\
\text { min. }\end{array}$} & \multicolumn{4}{|c|}{$\begin{array}{c}\text { Distensibility of shortbread dough semi-finished } \\
\text { products, } \mathrm{mm}\end{array}$} \\
\hline & & \multirow{2}{*}{$\begin{array}{c}\text { Control } \\
\text { (shortbread } \\
\text { dough) }\end{array}$} & \multicolumn{3}{|c|}{$\begin{array}{c}\text { Dough with the composition of seed } \\
\text { meals from sesame, walnut, flax }\end{array}$} \\
\hline & & & $\begin{array}{c}\text { Experi- } \\
\text { ment } \\
\text { No. } 1^{*} \\
\end{array}$ & $\begin{array}{c}\text { Experi- } \\
\text { ment } \\
\text { No. } 2^{* *} \\
\end{array}$ & $\begin{array}{c}\text { Experi- } \\
\text { ment } \\
\text { No. } 3^{* * *} \\
\end{array}$ \\
\hline 1 & 0 & 0.12 & 0.04 & 0.04 & 0.04 \\
\hline 2 & 1 & 0.20 & 0.08 & 0.08 & 0.10 \\
\hline 3 & 2 & 0.24 & 0.10 & 0.10 & 0.12 \\
\hline 4 & 3 & 0.30 & 0.12 & 0.12 & 0.14 \\
\hline 5 & 4 & 0.32 & 0.12 & 0.14 & 0.14 \\
\hline 6 & 5 & 0.34 & 0.14 & 0.16 & 0.14 \\
\hline 7 & 6 & 0.40 & 0.14 & 0.18 & 0.14 \\
\hline 8 & 7 & 0.42 & 0.14 & 0.18 & 0.14 \\
\hline 9 & 8 & 0.44 & 0.16 & 0.18 & 0.14 \\
\hline 10 & 9 & 0.46 & 0.16 & 0.20 & 0.14 \\
\hline 11 & 10 & 0.48 & 0.18 & 0.20 & 0.14 \\
\hline 12 & 15 & 0.52 & 0.20 & 0.22 & 0.16 \\
\hline 13 & 20 & 0.56 & 0.20 & 0.22 & 0.18 \\
\hline 14 & 25 & 0.60 & 0.22 & 0.24 & 0.18 \\
\hline 15 & 30 & 0.64 & 0.22 & 0.28 & 0.20 \\
\hline 16 & 40 & 0.70 & 0.22 & 0.30 & 0.20 \\
\hline 17 & 50 & 0.78 & 0.24 & 0.32 & 0.22 \\
\hline 18 & 60 & 0.80 & 0.24 & 0.32 & 0.22 \\
\hline 19 & 70 & 0.84 & 0.24 & 0.36 & 0.24 \\
\hline 20 & 80 & 0.90 & 0.26 & 0.36 & 0.24 \\
\hline 21 & 90 & 0.94 & 0.28 & 0.38 & 0.26 \\
\hline
\end{tabular}

Note: * - Experiment No. 1: dough where flour was replaced with the composition of meal from sesame, walnut, flax in the amount of $10 \% ; * *$ - Experiment No. 2: dough with flour was replaced with the composition of meal from sesame, walnut, flax in the amount of $20 \%$; *** - Experiment No. 3: dough where flour was replaced with the composition meal from sesame, walnut, flax in the amount of $30 \%$

Table 2

Structural-mechanical indicators for a shortbread dough semi-finished product, control and experimental samples containing the composition of meals

\begin{tabular}{|c|l|c|c|c|c|}
\hline $\begin{array}{c}\text { Indi- } \\
\text { cator }\end{array}$ & \multicolumn{1}{|c|}{ Indicator title } & Control & $\begin{array}{c}\text { Experiment } \\
\text { No. 1 }\end{array}$ & $\begin{array}{c}\text { Experiment } \\
\text { No. 2 }\end{array}$ & $\begin{array}{c}\text { Experiment } \\
\text { No. 3 }\end{array}$ \\
\hline$\gamma_{z v .}$ & Reverse deformation, $10^{-3} \mathrm{~m}$ & 0.56 & 0.17 & 0.24 & 0.17 \\
\hline$\gamma_{\text {nez. }}$ & Irreversible deformation, $10^{-3} \mathrm{~m}$ & 0.38 & 0.08 & 0.14 & 0.09 \\
\hline$\gamma_{\text {zag. }}$ & Overall deformation, $10^{-3} \mathrm{~m}$ & 0.94 & 0.25 & 0.38 & 0.26 \\
\hline$\tau$ & Shear stress, Pa & 130.80 & 196.20 & 196.20 & 196.20 \\
\hline$I$ & Pliability, $\mathrm{Pa}^{-1}$ & 0.0000072 & 0.0000013 & 0.0000019 & 0.0000013 \\
\hline$G_{p r .}$ & $\begin{array}{l}\text { Conditional instantaneous modu- } \\
\text { lus of elasticity, } \times 10^{3} \mathrm{~Pa}\end{array}$ & 0.93 & 3.924 & 4.08 & 3.270 \\
\hline$G_{e l .}$ & Highly elastic module, $\times 10^{3} \mathrm{~Pa}$ & 0.310 & 1.635 & 1.022 & 2.450 \\
\hline$\eta$ & Plastic viscosity, $\times 10^{2} \mathrm{~Pa} \cdot \mathrm{s}$ & 75.52 & 113.28 & 113.28 & 113.28 \\
\hline $\mathrm{K}$ & $\begin{array}{l}\text { Ratio of reverse deformation to } \\
\text { overall deformation }\end{array}$ & 0.60 & 0.67 & 0.62 & 0.65 \\
\hline$\Pi_{r}$ & Relative distensibility, \%: & 14.53 & 19.12 & 12.63 & 23.44 \\
\hline$\Pi_{l}$ & Relative plasticity, \%: & 40.38 & 33.09 & 37.89 & 35.16 \\
\hline$E_{l}$ & Relative elasticity, \%: & 45.09 & 47.79 & 49.47 & 41.41 \\
\hline
\end{tabular}


It was established that adding the composition of meals from sesame, walnut, flax to a shortbread dough semi-finished product alters its characteristics. Most characteristics demonstrate positive dynamics, which testifies to the effectiveness of adding meals. Fig. 1 shows the dynamics of deformation of shortbread dough semi-finished products containing the composition of meals from sesame, walnut, flax.

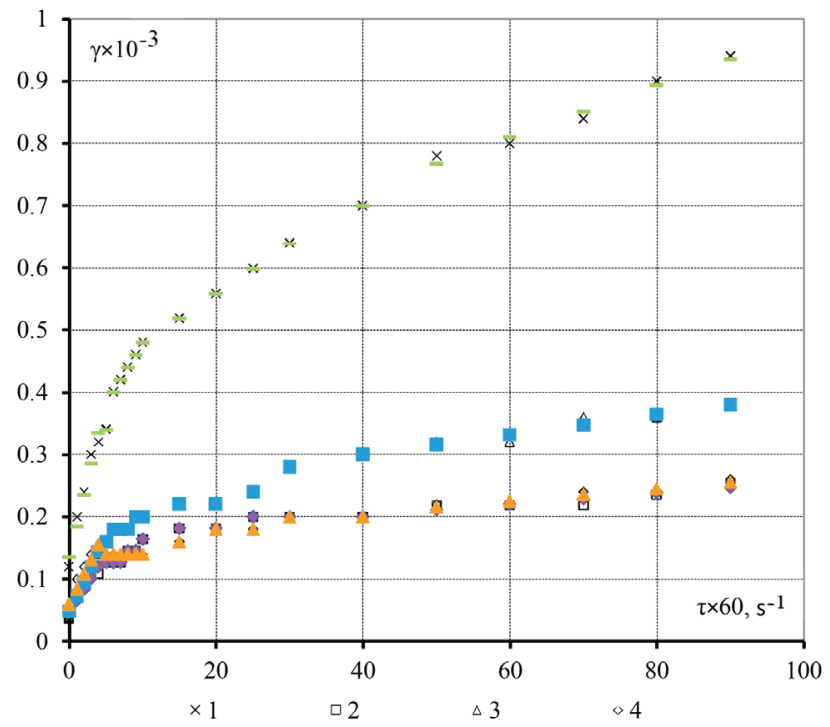

Fig. 1. Deformation of samples of shortbread dough semi-finished products: 1 - shortbread semi-finished product without additives; 2 - shortbread semi-finished product with wheat flour replaced with the composition of seed meal from sesame, walnut, flax in the amount of $10 \% ; 3$ - shortbread semi-finished product with wheat flour replaced with the composition of seed meal from sesame, walnut, flax in the amount of $20 \% ; 4$ - shortbread semi-finished product with wheat flour replaced with the composition of seed meal from sesame, walnut, flax in the amount of $30 \%$

Our research has shown that the total deformation of a dough semi-finished product reduces (Fig. 1). Adding the composition of the proposed meals to a shortbread dough semi-finished product changes its structural and mechanical indicators compared with control sample. The change in plastic viscosity occurs at the expense of reduced gluten.

The experiments have shown that structural-mechanical characteristics change nonlinearly. Primarily, this is due to the different content of chemical elements in a dough semi-finished product that cause different performance. The compositions containing $10 \%$ and $30 \%$ demonstrate certain similarity in the examined indicators.

The calculated indicators of distensibility, plasticity, and elasticity for a shortbread dough semi-finished product are shown in Fig. 2. It was established that replacing flour with the composition of meals in a shortbread dough semi-finished product (Fig. 2) changes the distensibility, as well as plastic and elastic properties. For control sample, the overall deformation is greater, which is why the magnitude for distensibility is greater by $65.24 \%, 64.69 \%$, and $55.88 \%$ for experiments No. $1-3$, respectively.

It was established that the best characteristics of a dough semi-finished product were observed during experiment No. 2 when adding meals in the amount of $20 \%$. Compared with control sample, there is an improvement in the characteristics of distensibility, plasticity, and elasticity.

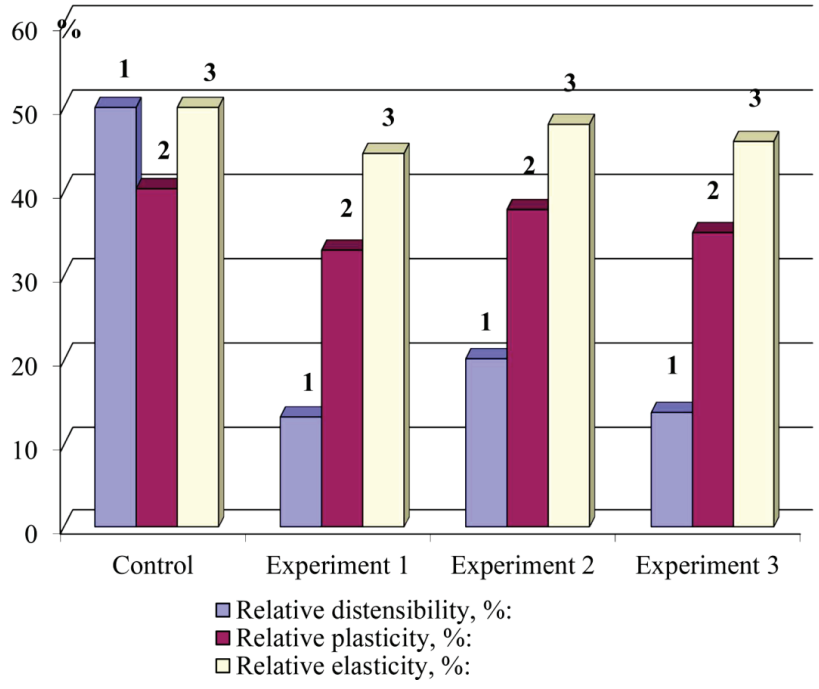

Fig. 2. Results of research into determining indicators for distensibility, plasticity, and elasticity for shortbread dough semi-finished product

\section{2. Results of research into the chemical composition} of shortbread biscuits

It is known that nutritional value of shortbread biscuits depends on their content of proteins, fats, carbohydrates, vitamins, and minerals. The specified substances and microelements directly affect the quality and usefulness of finished products. Therefore, we performed a study into determining the chemical composition of shortbread biscuits, the results of which are summarized in Tables 3, 4.

Table 3

Chemical composition of shortbread biscuits (control) per $100 \mathrm{~g}$

\begin{tabular}{|c|c|c|c|c|}
\hline \multirow[b]{2}{*}{ Indicator } & \multirow{2}{*}{$\begin{array}{l}\text { Measure- } \\
\text { ment unit }\end{array}$} & \multicolumn{3}{|c|}{ Meal } \\
\hline & & $\begin{array}{l}\text { flax } \\
\text { seed }\end{array}$ & $\begin{array}{c}\text { sesame } \\
\text { seed }\end{array}$ & $\begin{array}{l}\text { walnut } \\
\text { seed }\end{array}$ \\
\hline \multicolumn{5}{|c|}{ Micronutrients } \\
\hline Protein & \multirow{4}{*}{$\mathrm{g}$} & 28.00 & 37.82 & 44.83 \\
\hline Fat & & 10.00 & 4.00 & 4.40 \\
\hline Carbohydrates & & 37.00 & 23.78 & 20.31 \\
\hline including: Cellulose & & 35.00 & 2.00 & 7.60 \\
\hline \multicolumn{5}{|c|}{ Minerals } \\
\hline Potassium & \multirow{6}{*}{$\mathrm{mg}$} & 790.00 & 968.81 & $1,908.00$ \\
\hline Calcium & & $1,140.00$ & $2,873.29$ & 356.32 \\
\hline Magnesium & & 380.00 & $1,052.63$ & 568.97 \\
\hline Sodium & & 54.00 & 146.20 & 9.00 \\
\hline Phosphorus & & 600.00 & 616.00 & $1,620.00$ \\
\hline Ferrum & & 77.00 & 30.40 & 6.61 \\
\hline Iodine & \multirow{5}{*}{$\mu g$} & 9.00 & - & 8.20 \\
\hline Cobalt & & 0.71 & 30.20 & 20.98 \\
\hline Manganese & & 770.00 & - & $5,719.00$ \\
\hline Copper & & 150.00 & - & $1,514.00$ \\
\hline Selenium & & 171.00 & - & - \\
\hline \multicolumn{5}{|c|}{ Vitamins } \\
\hline A & \multirow{6}{*}{$\mathrm{mg}$} & 0.10 & - & 60.09 \\
\hline $\mathrm{C}$ & & 14.00 & - & 4.80 \\
\hline $\mathrm{B}_{1}$ & & 1.07 & 1.53 & 1.09 \\
\hline $\mathrm{B}_{2}$ & & 0.40 & 0.78 & 0.37 \\
\hline $\mathrm{E}$ & & 0.55 & 2.00 & 50.00 \\
\hline $\mathrm{PP}$ & & 2.10 & 7.80 & 2.87 \\
\hline $\mathrm{B}_{9}$ & $\mu \mathrm{g}$ & 4.20 & 4.00 & 221.26 \\
\hline
\end{tabular}


Table 4

Chemical composition of shortbread biscuits with the composition of meals

\begin{tabular}{|c|c|c|c|c|}
\hline Indicator & $\begin{array}{c}\text { Control (short- } \\
\text { bread biscuit) }\end{array}$ & $\begin{array}{c}\text { Experiment 1 } \\
\text { (shortbread biscuits with 10\% } \\
\text { of meal) }\end{array}$ & $\begin{array}{c}\text { Experiment 2 } \\
\text { (shortbread biscuits with 20 \% } \\
\text { of meal) }\end{array}$ & $\begin{array}{c}\text { Experiment 3 } \\
\text { (shortbread biscuits with 30 \% } \\
\text { of meal) }\end{array}$ \\
\hline Protein, g & 4.59 & 7.90 & 11.21 & 14.52 \\
\hline Cellulose, g & 0.72 & 2.06 & 3.40 & 4.75 \\
\hline Calcium, mg & 15.3 & 148.42 & 281.54 & 206.73 \\
\hline Magnesium, $\mathrm{mg}$ & 16.7 & 77.98 & 142.36 & 2.07 \\
\hline Iodine, $\mu \mathrm{g}$ & 0.40 & 0.96 & 4.52 & 6.58 \\
\hline Vitamin $\mathrm{E}, \mathrm{mg}$ & 0.50 & 2.53 & 5.55 & 15.42 \\
\hline Selenium, $\mu \mathrm{g}$ & 0.25 & 5.17 & 10.29 & 2.66 \\
\hline
\end{tabular}

Thus, we have calculated the chemical composition for a shortbread dough semi-finished product. The content of macronutrients, minerals, and vitamins per $100 \mathrm{~g}$ of mass was determined. It was established that flax seed meal contains the highest amount of fiber, ferrum, iodine, selenium. For sesame seeds meal, calcium, magnesium, sodium, cobalt, vitamins $\mathrm{B}_{1}$ and $\mathrm{B}_{2}$. For walnut kernel meal, protein, phosphorus, manganese, vitamin $\mathrm{A}$.

Increasing the percentage content of meals in the dough increases the total content of protein, cellulose, calcium, magnesium, iodine, and other nutrients (Table 4). Thus, the increase in cellulose during experiments No. 1, No. 2, and No. 3, compared with control, is: by 1.7 times, by 2.4 times, and by 3.2 times, respectively. The content of other substances significantly increases as well. The highest content is observed for calcium ( $414.66 \mathrm{mg}$ for experiment $3 \mathrm{com}$ pared with $15.3 \mathrm{mg}$ for control) and selenium (15.42 $\mu \mathrm{g}$ for experiment 3 compared with $0.25 \mu \mathrm{g}$ for control). That has a positive effect on the overall benefit of consuming shortbread biscuits.

\section{3. Results of research into sensory evaluation}

We performed sensory evaluation of shortbread dough semi-finished products containing the compositions of oilseed meals. The developed products were organoleptically assessed by a tasting board. The results from sensory evaluation of shortbread dough semi-finished products are shown in Fig. 3.

Based on our study, the main indicators for shortbread dough semi-finished products with the compositions of oilseed meals have been defined. Sensory evaluation of the dough semi-finished product has confirmed its high organoleptic indicators. This testifies to that the addition of the proposed meals improves the characteristics of finished products while maintaining indicators at a high level.

We have undertaken research and performed calculation of the chemical composition of shortbread biscuits to which, instead of flour, $10 \%, 20 \%$, and $30 \%$ of a meal composition were introduced. It was established that the best characteristics were observed during experiment No. 2 (the meal content is $20 \%$ ). The content of protein in it increased by 2.4 times, selenium - by 41.2 times, cellulose - by 4.7 times, calcium - by 18.4 times, magnesium - by 8.5 times, vitamin $\mathrm{E}-$ by 9.1 times. Thus, using the composition of meals in the technology of shortbread biscuits significantly increases its nutritional value.
Physical appearance
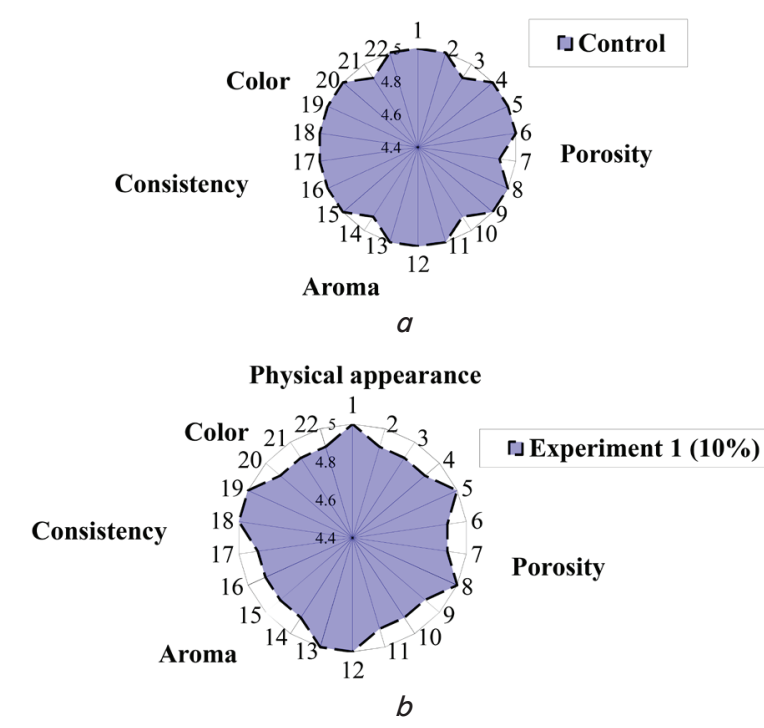

Physical appearance

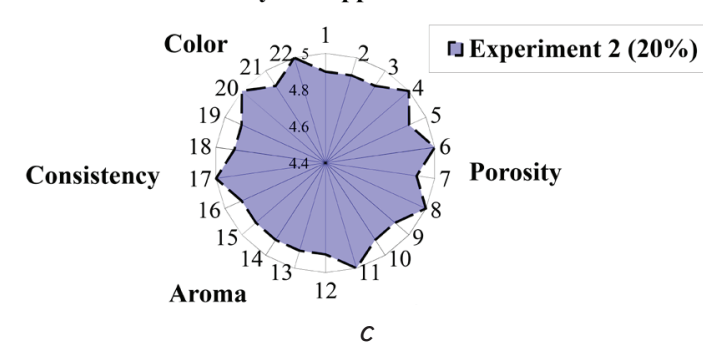

Physical appearance

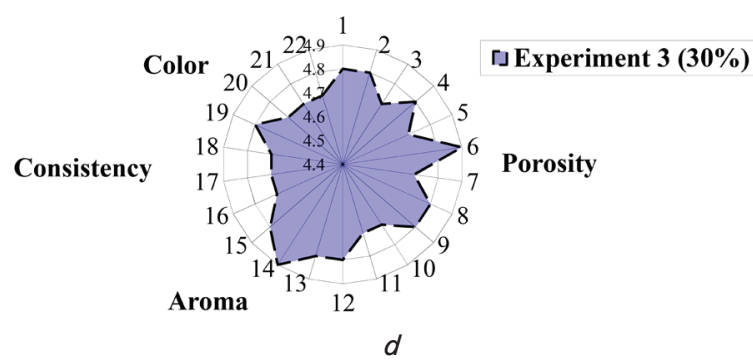

Fig. 3. Profile of sensory evaluation of a dough semi-finished product with the composition of seed meals from sesame, walnut, flax: $a$ - control; $b$ - experiment No. 1 (90:10); $c$ - experiment No. 2 (80:20); $d-$ experiment No. 3 (70:30) 


\section{Discussion of results of studying \\ the expediency of using oilseed meals in the technology of making products from shortcake dough}

Based on our study, it was found that adding meals in the amount of $10 \%$ instead of flour decreases the overall deformation of a shortbread dough semi-finished product by $70.45 \%$. This indicates that the structure of dough does change. Dough becomes less elastic and thinly stretched. This happens at the expense of reducing the amount of protein, starch and lipids of flour. It was established that the distensibility of dough with meals is less than that of control. This indicates that shortbread dough will be more brittle at baking, which is a positive result. Adding meals in the amount of $20 \%$ and $30 \%$ decreases the overall deformation by $57.86 \%$ and $70.36 \%$, respectively, since the amount of gluten is reduced.

In this case, replacing wheat flour in a shortbread dough semi-finished product with the compositional mixture from meals contributes to a change in instantaneous modulus of elasticity. In control, the modulus of elasticity is equal to $0.93 \cdot 10^{3} \mathrm{~Pa}$, for the first experiment $-3.924 \cdot 10^{3} \mathrm{~Pa}$, for the second experiment $-4.08 \cdot 10^{3} \mathrm{~Pa}$, for the third experiment $3.270 \cdot 10^{3} \mathrm{~Pa}$. The indicator for elastic modulus changes during experiments compared with control and equals $0.310 \cdot 10^{3} \mathrm{~Pa}$, for the first experiment $-1,635 \cdot 10^{3} \mathrm{~Pa}$, for the second experiment $-1.022 \cdot 10^{3} \mathrm{~Pa}$, and for the third experiment $-2.450 \cdot 10^{3} \mathrm{~Pa}$. Because the distensibility of dough in control exceeds that observed in the experiments, then the values for distensibility and elasticity will be greater for the control sample. This is due to the fact that the dough with the composition of meals does not stretch more than control because they contain less gluten.

The results of our study have established that the examined samples of shortbread dough containing the composition of meals demonstrate a decrease in the amount of gluten. In addition, the elastic properties of gluten decrease while its distensibility reduces. Along with this, the meals do not form gluten due to their interaction with proteins of flour, and, first and foremost, with a more reactive fraction - gliadin. It was established that the complexes form that are lost when gluten is washed, thereby changing the ratio of fractions of gliadin - glutenin in gluten in favor of glutenin while gluten strengthens. Given the reduction of gluten content in shortbread dough, in its distensibility and elasticity, one can predict changes in the structural-mechanical properties of shortbread dough. By knowing the structural-mechanical characteristics for shortbread dough, there is an opportunity to predict changes in them depending on the different content of a meal composition.

During sensory evaluation, it was determined that the addition of $30 \%$ of a meal composition changes the color of shortbread dough, which is unacceptable. It was established that the rational amount when adding a meal composition is $20 \%$. The developed products with the addition of meals have the improved nutritional and biological value, and demonstrate enhanced friability.

Thus, we have explored the structural and mechanical characteristics of shortbread dough with the addition of seed meals from sesame, walnut, and flax. That has made it possible to establish the optimal ratio of the specified meals, which could be added to a shortbread dough semi-finished product. This increases the quality of fini- shed products without substantial deterioration in sensory indicators.

The performed calculation of chemical composition of shortbread biscuits has confirmed the theoretical assumptions about the expediency of applying the seed meals from sesame, walnut, and flax as a supplement to shortbread dough. It was established that adding the specified meals increases the content of macronutrients, minerals, and vitamins per $100 \mathrm{~g}$ of mass. This is a positive factor that affects the quality and benefits of finished products. The performed sensory evaluation of the organoleptic indicators of finished products containing a composition of the specified meals has confirmed the effectiveness of the proposed solutions.

One should point to certain weaknesses in the research conducted. In the theoretical aspect, it would be advisable to perform a more accurate chemical analysis of shortbread biscuits considering all possible components. From a practical point of view, it would be appropriate to undertake a research aimed at introducing a larger percentage range of a meal composition instead of flour. This will increase the likelihood of the proper choice of the content of meals for a shortbread dough semi-finished product.

In the further research, it might be promising to develop a range of new kinds of shortbread cookies with added supplements based on oilseed meals and to implement them at the enterprises of restaurant business.

\section{Conclusions}

1. We have examined the structural-mechanical characteristics of shortbread dough with the addition of seed meals from sesame, walnut, and flax. It was found that the indicators for elasticity, plasticity, and distensibility reduce, in comparison with a control sample, by $4 \%$ to $40 \%$. The specified indicators are observed when adding the meals from sesame, walnut, and flax with a content from $10 \%$ to $30 \%$. Adding meals helps decrease the amount of gluten in flour, which is a positive factor for making shortbread dough. Adding a composition of the specified meals in the ratio of 1.5:2:1.5 to shortbread dough increases the content of protein, cellulose, macro- and micro-elements.

2. We have calculated the chemical composition for a shortbread dough semi-finished product and established the content of macronutrients, mineral substances, and vitamins per $100 \mathrm{~g}$ of mass. The expediency of using them has been confirmed experimentally by developing a technology for pastry products made from shortbread dough with the meals of oilseeds. It has demonstrated an increase in, protein content, by 2.4 times, selenium - by 41.2 times, cellulose - by 4.7 times, calcium - by 18.4 times, magnesium - by 8.5 times, vitamin $\mathrm{E}$ - by 9.1 times. It was established that the developed functional products have improved nutritional and biological value. More ways to use shortbread dough with meals have been proposed.

3. We have conducted sensory evaluation of shortbread dough semi-finished products with the meals of oilseeds. It was proven that gluten capability to stretching decreases while dough becomes less plastic and it does not degrade the overall performance. It was established that the fragility of finished shortbread biscuits increases. It was determined that the best sensory indicators were demonstrated by the sample with a $20 \%$ content of meals in flour. 


\section{References}

1. Tekhnolohiya kharchovykh produktiv funktsionalnoho pryznachennia: monohrafiya / Mazaraki A. A., Peresichnyi M. I., Kravchenko M. F., Karpenko P. O., Peresichna S. M.; M. I. Peresichnyi (Ed.). 2-he vyd., pererob. ta dop. Kyiv: Kyiv. nats. torh.-ekon. un-t., 2012. 1116 p.

2. Dubina A. A., Letuta T. M., Yancheva M. O. Tovaroznavstvo produktiv funktsionalnoho pryznachennia. Kharkiv: Vydavnytstvo Derzhavnoho universytetu kharchuvannia i torhivli, 2015. 189 p.

3. Povnotsinne kharchuvannia: innovatsiyni aspekty tekhnolohiy, enerhoefektyvnoho vyrobnytstva, zberihannia ta marketynhu: kol. monohr. / V. V. Yevlash, V. O. Potapova, N. L. Savytskoi (Eds.). Kharkiv: KhDUKhT, 2015. 580 p.

4. Weststrate J. A., van Poppel G., Verschuren P. M. Functional foods, trends and future // British Journal of Nutrition. 2002. Vol. 88, Issue S2. P. S233-S235. doi: https://doi.org/10.1079/bjn2002688

5. Kravchenko M. F. Innovatsiyni tekhnolohiyi kharchovykh vyrobnytstv: monohrafiya / V. A. Piddubnyi (Ed.). Kyiv: KondorVydavnytstvo, 2017. 374 p.

6. Shimizu M. Functional Food in Japan: Current status and future of gut-modulating food // Journal of Food and Drug Analysis. 2012. Vol. 20. P. 213-216.

7. Kravchenko M., Pop T. Khimichnyi i fraktsiynyi sklad poroshku z lystia voloskoho horikha // Tovary i rynky. 2014. Issue 2. P. 124-131.

8. Shydakova-Kameniuka O. H., Lysiuk H. M. Vyznachennia ratsionalnoho dozuvannia nasinnia lonu do pisochnoho pechyva // Prohresyvni tekhnika ta tekhnolohiyi kharchovykh vyrobnytstv restorannoho hospodarstva i torhivli. 2009. Issue 1. P. 347-353.

9. Soto-Cerda B. J., Duguid S., Booker H. Association mapping of seed quality traits using the Canadian flax // Academic research paper on Biological sciences. 2014. P. 344-352.

10. Modelling the effects of psyllium and water in gluten-free bread: An approach to improve the bread quality and glycemic response / Fratelli C., Muniz D. G., Santos F. G., Capriles V. D. // Journal of Functional Foods. 2018. Vol. 42. P. 339-345. doi: https://doi.org/ 10.1016/j.jff.2018.01.015

11. Complex indicator of quality of sugars and sugar substitutes and their use in the production of confectionery products / Dorokhovych A. M., Dorokhovych V. V., Mazur L. S., Pysarets O. P. // Prodovolchi resursy. 2018. Issue 10. P. 88-100.

12. Kravchenko M., Yaroshenko N. Study of food and energy values of new gingerbread types // EUREKA: Life Sciences. 2017. Issue 5. P. 53-60. doi: https://doi.org/10.21303/2504-5695.2017.00421

13. Lysiuk H. M., Shydakova-Kameniuka O. H., Fomina I. M. Tekhnolohiya boroshnianykh kondyterskykh vyrobiv z vykorystanniam yadra soniashnykovoho nasinnia: monohrafiya. Kharkiv: KhDUKhT, 2009. 145 p.

14. Study on the Efficiency of Grape Seed Meals Used as Antioxidants in Layer Diets Enriched with Polyunsaturated Fatty Acids Compared with Vitamin E / Olteanu M., Criste R., Panaite T., Bunduc V., Panaite C., Ropota M., Mitoi M. // Revista Brasileira de Ciência Avícola. 2016. Vol. 18, Issue 4. P. 655-662. doi: https://doi.org/10.1590/1806-9061-2016-0230

15. Abramova A. H. Zastosuvannia poroshku chornoplidnoi horobyny $\mathrm{v}$ tekhnolohiyi biskvitiv funktsionalnoho pryznachennia typu «Chervonyi oksamyt» // Zdobutky ta perspektyvy rozvytku kondyterskoi haluzi: Mizhnarodna naukovo-praktychna konferentsiya. Kyiv: NUKhT, 2017. P. 126-128.

16. Stickiness in foods: a review of mechanisms and test methods / Adhikari B., Howes T., Bhandari B. R., Truong V. // International Journal of Food Properties. 2001. Vol. 4, Issue 1. P. 1-33. doi: https://doi.org/10.1081/jfp-100002186

17. Horalchuk A. B., Pyvovarov P. P., Hrynchenko O. O. Reolohichni metody doslidzhennia syrovyny i kharchovykh produktiv ta avtomatyzatsiya rozrakhunkiv reolohichnykh kharakterystyk: navch. pos. Kharkiv: KhDUKhT, 2006. 242 p.

18. DSTU 3781:2014. Pechyvo. Zahalni tekhnichni umovy. Kyiv: Derzhspozhyvstandart Ukrainy, 2015. 16 p.

19. DSTU 4910:2008. Vyroby kondyterski. Metody vyznachennia masovykh chastok volohy ta sukhykh rechovyn. Kyiv: Derzhspozhyvstandart, 2008. $16 \mathrm{p}$.

20. DSTU 5024:2008. Vyroby kondyterski metody vyznachannia kyslotnosti ta luzhnosti. Kyiv: Derzhspozhyvstandart, 2008. 16 p.

21. TU U 10.4-38667335-002:2014. «Produkty pererobky z nasinnia oliinykh kultur. Tekhnichni umovy».

22. Pavlov O. Zbirnyk retseptur boroshnianykh kondyterskykh i zdobnykh bulochnykh vyrobiv: navch.-prakt. pos. Kyiv: Profknyha, 2018. $336 \mathrm{p}$.

23. Tiutiakh O. Strukturno-mekhanichni vlastyvosti kharchovykh produktiv // Materialy mizhnar. stud. nauk.-tekhn. konf. «Pryrodnychi ta humanitarni nauky. Aktualni pytannia». Ternopil, 2018. P. 166-167. 